\title{
PROBLEM RESOCJALIZACJI SPRAWCÓW PRZESTECPSTW SEKSUALNYCH W ŚWIETLE TEORII DEZINTEGRACJI POZYTYWNEJ KAZIMIERZA DĄBROWSKIEGO
}

\begin{abstract}
Streszczenie. Teoria dezintegracji pozytywnej Kazimierza Dąbrowskiego jest dość złożoną koncepcją teoretyczną o charakterze modelu naukowego. Jej analiza może dać ciekawy wgląd w różnoraką problematykę, na przykład w kwestię resocjalizacji sprawców przestępstw seksualnych. Celem artykułu jest opisanie samej teorii oraz zastosowanie jej zasad do praktycznego zagadnienia penalizacji i resocjalizacji sprawców. Wnioski obejmują zarówno sferę zagadnień prawnych, jak i politycznych.
\end{abstract}

Slowa kluczowe: psychologia, przestępstwa seksualne, odpowiedzialność prawna, teoria dezintegracji pozytywnej, rozwój osobisty.

\section{TEORIA DEZINTEGRACJI POZYTYWNEJ (TDP)}

Teoria dezintegracji pozytywnej (w skrócie TDP) jest autorską koncepcją Kazimierza Dąbrowskiego. Ma ona dosyć paradoksalny charakter, gdyż jej myśl przewodnią stanowi idea, wedle której najdynamiczniejszy rozwój jednostki odbywa się poprzez zaburzenia psychiczne. Dowodem na prawdziwość tego oryginalnego toru myśli wybitnego psychiatry są, w jego własnych pismach, liczne życiorysy słynnych ludzi - Sørena Kierkegaarda, Franza Kafki, Witkacego, Izaaka Newtona czy Blaise’a Pascala (Dąbrowski 1986, 26-36). Co ważne, teoria ta ma jednak charakter stricte naukowy, mimo iż jednocześnie była zaczątkiem całej filozofii rozwoju, stworzonej przez tego Polaka. Stąd wziął się częsty zarzut, że stanowi ona przejaw filozofii rozumianej jako twórczość, w której można stawiać tezy niepoparte naukowymi dowodami, a nie nauka ze wszystkimi jej metodologicznymi wymaganiami. Zarzut ten jest w moim odczuciu nieprawdziwy. Dąbrowski zdefiniował ściśle wszystkie nowe terminy wprowadzane przez siebie do terminów już wcześniej ugruntowanych $\mathrm{w}$ psychologii. W dodatku prowadził on liczne badania i statystyki, komentowane następnie szeroko przez zagranicznych autorów, teoria ta zatem, będąca jednocześnie typowym, naukowym modelem, ma bez wątpienia pochodzenie empiryczne.

* Uniwersytet Łódzki, Wydział Prawa i Administracji, Katedra Teorii i Filozofii Prawa, limoncino111@googlemail.com. 
Na początku, w skrócie, przedstawię jej konstrukcję, aby potem przejść do rozważań nad jej przydatnością dla zagadnienia resocjalizacji więźniów. Dąbrowski wyróżnił pięć zasadniczych nadwrażliwości psychicznych, mających zapewne źródło w konkretnych obszarach mózgu, u jednych lepiej, u drugich gorzej bądź w ogóle niewykształconych: psychoruchową - funkcję organicznego nadmiaru energii lub nadmiernej pobudliwości systemu nerwowo-mięśniowego, objawy: szybkie mówienie, gwałtowne ruchy, mania podróżowania, potrzeba natychmiastowego działania; zmysłową - funkcję wzmożonego odczuwania przyjemności zmysłowych, objawy: potrzeba luksusu, stereotypowego piękna, mody, różnorodności doświadczeń seksualnych, brak umiarkowania w jedzeniu i piciu, liczne, acz powierzchowne relacje z innymi ludźmi; uczuciową - funkcję odczuwania związków emocjonalnych, objawy: silne przywiązanie do ludzi, stworzeń i miejsc, demonstracje nie pustych emocji, a związków emocjonalnych; wyobrażeniową - funkcję bogatego kojarzenia obrazów i wrażeń, objawy: inwencja twórcza, obrazowe i metaforyczne wypowiadanie się, nieodróżnianie prawdy od fikcji, strach przed nieznanym; intelektualną - funkcję wzmożonej pobudliwości intelektualnej, objawy: zadawanie dociekliwych pytań, żądza wiedzy, ciągłe analizowanie, uznanie dla logiki, zajmowanie się problemami teoretycznymi (Piechowski 1981, 109-123).

Pierwsze dwie są przeszkodami w rozwoju, mają charakter inwolucyjny. Trzy pozostałe stanowią potencjał twórczy człowieka, przy czym Dąbrowski zastrzega, że aby wspinaczka po kolejnych poziomach rozwoju psychicznego była możliwa, konieczne są aż dwie z tych trzech nadwrażliwości (Dąbrowski 1938). Zastrzeżenie to niesie za sobą daleko idące konsekwencje. W świetle badań empirycznych samego autora (prowadzonych głównie we Francji i Kanadzie ze względu na brak wsparcia finansowego w czasach PRL-u dla tak nowatorskich idei) oraz innych psychologów i psychiatrów wychodzi na jaw, iż niestety potencjał twórczy drzemie w bardzo niewielkiej części ludzkości. Prawdopodobnie nie więcej niż $15 \%$ osobników ma możliwość wybicia się ponad pierwsze dwa poziomy rozwoju, co czyni tę teorię zdatną głównie do pracy z jednostkami uzdolnionymi. Jednakże jako prawnicy potrafimy rozumować a contrario i w efekcie wydedukować, jaki może być słuszny sposób postępowania z pozostałą, mniej uzdolnioną, ale przecież równie ważną, jak nie ważniejszą ze względu na dużą liczbę, częścią ludzkości, w tym z jej najgorszą częścią w postaci między innymi przestępców seksualnych.

Poziomy rozwoju psychicznego, które ciągle wspominam, to: integracja pierwotna (poziom I), dezintegracja jednopoziomowa i jednokierunkowa (poziom II), dezintegracja wielopoziomowa spontaniczna (poziom III), dezintegracja wielopoziomowa zorganizowana (poziom IV), integracja wtórna (poziom V). Na każdym z poziomów występują charakterystyczne dla niego dynamizmy psychiczne (Dąbrowski 1979). Można w tym miejscu zapytać, w jaki sposób stwierdzić ich występowanie. Otóż istnieją dwa rozwiązania: samotna droga introspekcji bądź 
wizyta u psychologa czy psychiatry na serii profesjonalnych badań psychologicznych w celu zidentyfikowania tych dynamizmów i ich naukowego potwierdzenia.

Na poziomie pierwszym spotykamy niewiele dynamizmów, gdyż socjo- i psychopaci posiadają szczątkowe życie wewnętrzne. Są to: konflikt zewnętrzny, agresja, syntonia nastrojowa, ośrodek zarządzania w postaci prymitywnych popędów. Można tu zacytować genialnego egzystencjalistę, Karla Jaspersa, który wprawdzie odnosił się do hitlerowców, ale zakładamy, iż przestępcy seksualni są jednostkami o niewiele bardziej prospołecznym nastawieniu:

Hitler i jego kompani, w sumie drobna mniejszość kilkudziesięciu tysięcy ludzi, w ogóle nie czują winy moralnej, stoją więc poza nią. Są chyba zupełnie niezdolni do skruchy i przemiany. Są, jacy są. Wobec ludzi tego pokroju pozostaje tylko przemoc, sami bowiem uprawiają jedynie przemoc (Jaspers 1965, 102; tłum. Jan Garewicz).

Na drugim poziomie mamy ambiwalencje, ambitendencje, poczucie niższości wobec innych, zaniepokojenie o siebie, drugi czynnik (tu niezbędne wyjaśnienie - Dąbrowski wyróżnia trzy czynniki rozwojowe: czynnik pierwszy, czyli dziedziczność; czynnik drugi, czyli środowisko; czynnik trzeci, czyli autonomiczne procesy wewnętrzne), ośrodek zarządzania w postaci wielorakich ,chęci”. Na trzecim: pozytywne nieprzystosowanie, poczucie winy, poczucie wstydu, zdziwienie sobą, zaniepokojenie sobą, poczucie niższości wobec siebie, niezadowolenie z siebie, hierarchizacja, empatia, identyfikacja, konflikt wewnętrzny, ośrodek zarządzania w postaci zmiennego wznoszenia się i opadania między popędami a ideałem osobowym. Na czwartym: autonomia, autentyzm, odpowiedzialność, samowychowanie, autopsychoterapia, samokontrola, samoświadomość, przekształcenie wewnątrzpsychiczne, empatia, trzeci czynnik, stosunek podmiot - przedmiot w sobie, ośrodek zarządzania łączący harmonijnie „,chęci” z ideałem osobowym. Do najwyższego poziomu (V poziomu TDP) docierają już naprawdę nieliczni, choć najtrudniejszy jest przeskok między poziomem drugim (poziomem najcięższych zaburzeń, gdzie niewykluczone są nieprzezwyciężalne choroby) a trzecim, gdzie trzeba stawić czoła własnym lękom objawiającym się w formie nerwic, psychonerwic, a niekiedy nawet lekkich psychoz (Piechowski, 1981).

\section{PRZELOŻENIE TEORII NA PRAKTYKĘ I WNIOSKI SZCZEGÓŁOWE}

Warto od razu podkreślić, że Dąbrowski w swoich pracach nie zaprzecza oczywistej prawdzie, iż w przypadkach ciężkich schorzeń - schizofrenii, ostrych psychoz, paranoi itp., naturalnie nieodzowne musi być leczenie farmakologiczne, a nie droga psychoterapeutyczna (Dąbrowski, 1986).

Poziom I to poziom psychopatii i socjopatii. Te zaburzenia osobowości należą, przynajmniej jak do tej pory, do nieuleczalnych, choć dla osób na nie cierpiących nie stanowi to problemu - są one nierzadko jednostkami przebojowo idącymi 
przez życie, odnoszącymi sukces zawodowy, obdarzonymi wysokim ilorazem inteligencji. Takie osoby cechuje całkowity brak moralności. Jednocześnie nie miewają one zaburzeń psychicznych, które często zatrzymują w rozwoju kariery tych, którzy oprócz inteligencji posiadają też wrażliwość. Naturalnie, powyższy opis jednostek z I poziomu cechuje się przesadną obyczajową ocennością, użytą tu specjalnie, gdyż dla istoty pracy znaczenie mają tylko ci psycho- i socjopaci, którzy mogą potencjalnie uczestniczyć w przestępstwach o podłożu seksualnym. Rozkład IQ dla I poziomu nie jest przesunięty na osi w prawo względem np. poziomu III.

Teoria Dąbrowskiego pokazuje przede wszystkim, iż tworzenie własnej, pełnej, zindywidualizowanej osobowości to proces długotrwały, żmudny i wymagający pracowitości, a przez to kończący się sukcesem tylko u części jednostek. Pozostali do końca życia są targani charakterystycznymi dla drugiego poziomu dynamizmami ambiwalencji, ambitendencji i poczucia niższości wobec innych bądź są amoralnymi psychopatami i socjopatami. W takiej sytuacji powstaje pytanie, czy w ogóle istnieje jakakolwiek nadzieja na resocjalizację sprawców przestępstw tak poważnego kalibru, jak przestępstwa seksualne.

W tym miejscu nieodzowna wydaje się refleksja nad kluczowym dla artykułu zagadnieniem szans na reformę jednostek, pozwalających sobie na dokonywanie czynów zabronionych, klasyfikowanych jako przestępstwa seksualne. Badania przytaczane przez już typowo karnoprawną literaturę, a nie tylko przez pojedynczą, omawianą przeze mnie tutaj teorię psychologiczną spoza głównego nurtu dzisiejszej psychologii, zasadniczo potwierdzają wnioski płynące z TDP. Otóż wśród mężczyzn odbywających karę pozbawienia wolności wielu (mniej więcej co piąty) miało kontakt seksualny z kobietą, która nie ukończyła 15 lat, podobny był odsetek tych, którzy wykorzystali partnerkę, odurzając ją środkami psychoaktywnymi. Co trzeci doprowadził kobietę do współżycia seksualnego przemocą lub podstępem. Zaledwie niecałe dwie trzecie badanych osób w więzieniach ocenia tego typu sytuacje jako jednoznacznie negatywne z normatywnego punktu widzenia. Nieco ponad połowa akceptuje zdrady w stałym związku (wielu z nich za wystarczające uzasadnienie tego poglądu podaje nudę w związku, ciążę partnerki bądź naturalną poligamiczność mężczyzn) - chyba nie trzeba przywoływać więcej dowodów na zdemoralizowanie tej grupy społecznej, co dobrze koresponduje z opisem jednostek I poziomu TDP Dąbrowskiego (Łukaszek 2015, 329-330).

Niewątpliwie jednostki z poziomów III-V są zbyt bogate wewnętrznie i dojrzałe duchowo, by potrzebować realizacji funkcji wychowawczej prawa. Pewną niedorzecznością byłoby spodziewać się, że jednostki zdolne do autentycznego samowychowania się ni stąd, ni zowąd popełnią na przykład rozbój, nieuzasadniony stanem wyższej konieczności lub inną wyjątkową sytuacją, czy też przestępstwo o naturze seksualnej. Wesprzeć ten tok myślenia można argumentem cybernetycznym, wedle którego przestępstwo jest często wynikiem dużego odchylenia homeostatu od normy. To abstrakcyjne zdanie egzemplifikuje się w zwykłym ciągu 
przyczynowo-skutkowym, zgodnie z którym osoba skrajnie głodna dopuszcza się kradzieży jedzenia ze sklepu w celu przywrócenia sobie pełnej homeostazy. $\mathrm{W}$ odniesieniu do jednostek $\mathrm{z}$ poziomów III-V widzimy koherencję TDP z liberalnymi teoriami prawa. Przecież osobnicy z tej grupy w najlepszym wypadku zostaną lekko zdemoralizowani zaleceniami prawnymi, szczególnie że prawa niejednokrotnie wymagają wypełniania obowiązków pod względem moralnym kontrowersyjnych, jak choćby obowiązek płacenia podatków, którego moralna dwuznaczność wynika z mnogości koncepcji ekonomicznych, konceptualizujących sferę obciążeń podatkowych.

Z kolei wychowywanie jednostek z I poziomu to tylko idealistyczna mrzonka. Badania neuronaukowców dają wprawdzie pewne nadzieje, że za około dziesięć lat znajomość budowy ludzkiego mózgu (w szczególności całkowite zrozumienie działania mózgowego obwodu empatii) będzie już tak ogromna, iż stworzy szanse skutecznego leczenia jednostek ,zero-negatywnych”, do których, zgodnie z terminologią Simona Barona-Cohena, zalicza się psychopatów, narcyzów i osoby z zaburzeniem borderline (Baron-Cohen 2015, 175-179). Moim zdaniem grupe pacjentów klasyfikowaną przez współczesnych badaczy jako „zero-negatywni” i grupę pacjentów, których Kazimierz Dąbrowski uznawał za jednostki znajdujące się na I poziomie według teorii dezintegracji pozytywnej, można z grubsza utożsamić.

Natomiast jednostki miotające się w walce ze swoimi dynamizmami życia wewnętrznego na II poziomie (statystycznie najczęściej występującym poziomie w społeczeństwie) potrzebują wsparcia ze strony bodźców znacznie subtelniejszych niż, prymitywne jednak w sposobie oddziaływania, prawo. Pomocna dłoń psychoterapeuty może okazać się wybawieniem. Oddziaływanie na pacjenta bodźcami o charakterze etycznym, poznawczym czy ideologicznym może obudzić jego nadwrażliwość i skłonić do rozwoju w kierunku „Ja-transcendentalnego” (rozumianego tu zwyczajnie, psychologicznie, jako dążenia do ideału osobowości indywidualnej i społecznej, a nie w sensie filozofii Edmunda Husserla).

Konstatacje te prowadzą nas do wniosku, że zgodnie z intuicją podstawową funkcją prawa jest funkcja homeostatyczna, a więc w wymiarze praktycznym funkcja trzymania w ryzach jednostek patologicznych w rodzaju przestępców seksualnych, które nie popełniają złych uczynków tylko wówczas, gdy stają się one nieopłacalne na bazie chłodnej kalkulacji zysków i strat. Stąd postulat surowego karania przestępców, w tym przede wszystkim przestępców popełniających czyny o charakterze przestępstw seksualnych. Gdy prawo wymaga wypełniania przez członków społeczeństwa przykazań jakiejś etyki perfekcjonistycznej, zabiera się ono za mającą nieszczególny sens w świetle teorii Dąbrowskiego funkcję wychowawczą. Czy tylko w jej świetle? Literatura prawnokarna idzie w sukurs TDP, ogłaszając w najlepszym wypadku skuteczność oddziaływań resocjalizacyjnych na poziomie $20 \%$, z zaznaczeniem, iż częstsze jest nieosiąganie chociażby połowy tej wielkości (Pospiszyl 2015, 100). Państwo natomiast, wymagając realizacji etyki 
minimum, przy pomocy prawa osiąga ład i harmonię w społeczeństwie, eliminując z niego groźne jednostki poprzez pozbawienie ich wolności bądź trzymając je w ciągłym strachu przed sankcją. Tak dopełnia się wprowadzenie w życie funkcji homeostatycznej prawa.

Kolejną korzyścią płynącą z treści teorii Kazimierza Dąbrowskiego jest możliwość jasnego określenia adresatów prawa. Będą to zgodnie z intuicją osobnicy patologiczni - psychopaci i socjopaci z pierwszego poziomu TDP oraz jednostki spędzające swoje życie na pograniczu psychopatii i psychonerwicy z drugiego poziomu TDP (w tych kategoriach zresztą zmieszczą się niemal wszystkie osoby popełniające przestępstwa o podłożu seksualnym, wyjąwszy może osoby skazane niesłusznie i inne sporadyczne przypadki).

Następnie, mając już nakreśloną problematykę istotnych adresatów prawa, można przejść do postulatu umieszczenia właściwych jednostek po stronie twórców prawa zgodnego z moralnością i wpływającego na nią pozytywnie. Naturalnie, z TDP Dąbrowskiego wynika po prostu zalecenie bytności w tej grupie, w miarę możliwości, jednostek z poziomów IV-V. Takie osoby powinny, przynajmniej w teorii, zapewnić odpowiednio surową karę przestępcom seksualnym, jednocześnie nie wykluczając całkowicie szans na ich resocjalizację w przyszłości, gdy badania naukowe dadzą realniejszą nadzieję na wyższą skuteczność procesów resocjalizacyjnych. Pytanie, jak rozpoznać najlepszy materiał ludzki, mający docelowo tworzyć prawo dotyczące tej problematyki. To samo pytanie, rozumując a contrario, pozwoli rozpoznawać profile psychologiczne potencjalnych sprawców przestępstw seksualnych. Otóż wydaje się, że trzeba się kierować opisanymi wyżej przejawami nadwrażliwości i występowaniem u kandydatów odpowiednich dynamizmów psychicznych. By nie zostawić nas z tym problemem samych, polski psychiatra napisał jeszcze jedno, niezwykle oryginalne dzieło - Moralność w polityce, naszkicowawszy w nim ogólną typologię polityk i polityków na bazie swej teorii w celu ułatwienia przyszłym badaczom rozpoznawania jednostek, godnych niezwykle odpowiedzialnego zadania sprawowania władzy w państwie, w tym sprawiedliwego karania przestępców seksualnych. Poniżej przedstawię schematycznie i skrótowo jego propozycje, ponieważ są inspirujące:

I. Polityka na poziomie integracji prymitywnej (tu właśnie analogia do przestępców seksualnych będzie najoczywistsza).

Cechy charakterystyczne: dyktatorstwo prymitywne, oparte na cechach psychopatycznych dyktatora, osobiste ambicje, egoizm, okrucieństwo, polityka „narodowa” lub blokowa. Tworzenie „esencji” posłuszeństwa; bezwzględność, a nawet okrucieństwo w stosunku do wszystkiego, co ,inne”, indywidualne, autonomiczne i autentyczne. Brak wszelkiej demokracji i liberalizmu, brak stowarzyszeń, cenzura, metoda więzień i obozów koncentracyjnych. Przykłady osób reprezentujących ten kierunek: Hitler, Stalin, Trujillo, niektórzy dyktatorzy starożytni i średniowieczni, niektórzy carowie rosyjscy. 
II. Polityka dezintegracji jednopoziomowej i pogranicza dezintegracji wielopoziomowej spontanicznej.

Cechy charakterystyczne: rodząca się i rozwijająca, chociaż słaba hierarchia wartości. Postawa mieszana syntonii i empatii, zdolność do stawiania sobie problemów humanitarnych, polityka średniego zakresu, znacznie przytłumiony egoizm narodowy, potrzeba tworzenia ustaw i organizacji międzynarodowych, ale bez konsekwentnego ich rozwijania. Prądy liberalne, demokracja, jednocześnie $\mathrm{z}$ tendencją do zwyrodnienia, do tworzenia klik. Wstrząsy społeczno-polityczne, prądy degeneracyjne (rasistowskie, hippies itp.). Przykłady osób reprezentujących ten kierunek: Roosevelt, Churchill, Nixon.

III. Grupa pośrednia, głównie na poziomie trzecim.

Cechy charakterystyczne: ideały liberalne i tendencje do rozbijania tworzących się klik, to znaczy dopuszczanie do głosu jednostek i grup najbardziej kulturalnych o alterocentrycznych nastawieniach, walka z grupami i klikami wyznaczającymi rozwój kraju poprzez jednostronną dominację (ekonomiczną, narodową itp.), niewystarczająca siła z jednoczesną empatią, widzenie na bliski i daleki dystans, charakter psychonerwicowy polityki. Przykłady osób reprezentujących ten kierunek: John F. Kennedy, de Gaulle, Trudeau.

IV. Polityka na poziomie czwartym dezintegracji pozytywnej i pogranicza integracji wtórnej (te przykłady służą niejako zobrazowaniu przeciwległego bieguna naszej problematyki).

Cechy charakterystyczne: uniwersalizm i dbałość autentyczna o interesy zarówno własnego narodu, jak i innych, polityka dalekowzroczna z przewidywaniem dalekiej przyszłości, empatia, samoświadomość, wysoka postawa kontroli poprzez intelekt i uczucia wyższe, ścisła hierarchizacja wartości, wszechstronne przygotowanie z zakresu wiedzy o człowieku, a głównie jego funkcji wyższych, szeroka postawa filozoficzna. Przykłady osób reprezentujących ten kierunek: Sokrates, Lincoln, Dag Hammarskjold, Gandhi (Dąbrowski 1991, 81-83).

\section{WNIOSKI KOŃCOWE I OGÓLNE}

Ostatnim, najbardziej ryzykownym, ale może przez to ciekawym wnioskiem, jaki można by wyciągnąć przy wsparciu tej teorii, jest teza, iż filozofia liberalna, która opanowała w ostatnich wiekach Europę, doprowadza ją do powolnego upadku. Opiera się ona, jak wspominałem, na optymizmie antropologicznym, który ze swą niezachwianą wiarą w rozwojowość ludzkiej jednostki doprowadził już rządzących do pewności o ogromnych pokładach empatii w obywatelach państw Zachodu. Ta pozorna empatyczność (ale w płaszczyźnie politycznej już niestety realna w sferze rzeczywistych działań przy jednoczesnym jej braku w rozumieniu autentycznego dynamizmu psychicznego) ma przełożenie na rozwiązania prawne bieżących problemów, takich jak kwestia imigrantów. 
Rozwiązania te cechuje zgodność z typem moralności, który, jak pokazał Dąbrowski, charakteryzuje wyłącznie osobników mniej lub bardziej wybitnych, a nie przeciętnego człowieka, tkwiącego wciąż na poziomie prostych syntonii, a nie głębokiej, empatycznej właśnie miłości w rozumieniu tak Dąbrowskiego, jak Ericha Fromma z O sztuce miłości. Istotne zróżnicowanie, istniejące między ludźmi w poziomach dynamizmu empatii, dostrzegają zresztą naukowcy w najnowszych badaniach (Baron-Cohen 2015, 37-41). W efekcie takiego zapatrzenia w ideologię liberalną oraz manipulacji ze strony władz masy ludzkie są wprowadzane w błąd w zakresie samowiedzy. Poprzez system prawny, środki masowego przekazu i propagandę próbuje się utrzymać czyste ideały liberalne, odnosi to jednak coraz słabsze skutki, gdyż i tak prasa regularnie donosi o sukcesach opcji politycznych o nastawieniu nacjonalistycznym (wybory w Austrii, Brexit). Ta inżynieria społeczna może mieć groźne skutki w postaci ostatecznego wyparcia z terenów państw Zachodu łacińskich wzorców cywilizacyjnych. W takim sensie wynikająca z ideologicznego zaślepienia „empatia” zabija Europę. Empatia jest wprawdzie jednym z najcenniejszych zasobów tego świata (Baron-Cohen 2015, 9-11), jednak nie należy zapominać, iż na razie jest to zasób bardzo ograniczony nawet w najbardziej rozwiniętym europejskim kręgu kulturowym. Wydaje się, że założenia teorii dezintegracji pozytywnej dobrze naświetliły, jak długa droga czeka przeciętną jednostkę do osiągnięcia autentycznego dynamizmu empatii rozumianej jako cecha stała, a nie tylko stan przejściowy. Z kolei wśród przedstawicieli innych cywilizacji, podobnie jak wśród sprawców przestępstw seksualnych, empatia wydaje się być „surowcem” niemalże niewystępującym, a więc w konfrontacji z nimi empatia okazywana obecnie konsekwentnie w płaszczyźnie politycznej okaże się całkowicie dezadaptacyjna. Rzecz jasna wniosek ten nie stoi w sprzeczności z postulatem pobudzania empatii w relacjach między pojedynczymi jednostkami, rodzinami, nawet pochodzącymi ze skrajnie przeciwstawnych cywilizacji. Intymność konkretnej relacji międzyludzkiej a twarde polityczne realia (a już w szczególności realia zakładów karnych, w których osadzeni są przestępcy seksualni) to dwa różne, na razie nieporównywalne światy, choć miejmy nadzieję, że w przyszłości zaczną się wzajemnie coraz bardziej przenikać. Zbliżanie się tych światów wydaje się być, jak do tej pory, możliwe do częściowej i bardzo powolnej realizacji, zdecydowanie raczej oddolnie (przez społeczeństwo) niż odgórnie (przez państwo).

\section{BIBLIOGRAFIA}

Baron-Cohen, Simon. 2015. Teoria zła. O empatii i genezie okrucieństwa. Tł. Agnieszka Nowak. Sopot: Smak Słowa.

Dąbrowski, Kazimierz. 1938. „Typy wzmożonej pobudliwości psychicznej”. Biuletyn Instytutu Higieny Psychicznej 1 (1): 12-19.

Dąbrowski, Kazimierz. 1979. Zdrowie psychiczne. Warszawa: Państwowe Wydawnictwo Naukowe. 
Dąbrowski, Kazimierz. 1986. Trud istnienia. Warszawa: Wiedza Powszechna.

Dąbrowski, Kazimierz. 1989. Elementy filozofii rozwoju. Warszawa: Polskie Towarzystwo Higieny Psychicznej.

Dąbrowski, Kazimierz. 1991. Moralność w polityce. Wielopoziomowość funkcji uczuciowych i popędowych w życiu społecznym i politycznym oraz instytucjach. Warszawa: BIS.

Jaspers, Karl. 1965. Hoffnung und Sorge. Monachium: Piper.

Łukaszek, Maria. 2015. „Agresja seksualna wobec kobiet - doświadczenia i opinie mężczyzn odbywających karę pozbawienia wolności”. W Resocjalizacja penitencjarna w kontekstach interdyscyplinarnych. Red. Danuta Kowalczyk, Adam Szecówka, Sławomir Grzesiak. 319-332. Wrocław: Oficyna Wydawnicza Atut - Wrocławskie Wydawnictwo Oświatowe.

Piechowski, Michael. 1981. „Zdrowie psychiczne jako funkcja rozwoju psychicznego (Mental health as a function of psychological development)". Tł. Krystyna Dudziak. W Zdrowie psychiczne. Red. Kazimierz Dąbrowski. 91-128. Warszawa: Państwowe Wydawnictwo Naukowe. Pospiszyl, Kazimierz. 2015. „Istota i postacie trudności w resocjalizacji przestępców seksualnych”. W Resocjalizacja penitencjarna w kontekstach interdyscyplinarnych. Red. Danuta Kowalczyk, Adam Szecówka, Sławomir Grzesiak. 97-104. Wrocław: Oficyna Wydawnicza Atut

- Wrocławskie Wydawnictwo Oświatowe.

Adam Kędrzyński

\title{
THE PROBLEM OF RESOCIALISATION OF CRIMINALS COMITTING SEXUAL CRIMES IN THE LIGHT OF KAZIMIERZ DĄBROWSKI'S THEORY OF POSITIVE DISINTEGRATION
}

\begin{abstract}
Kazimierz Dąbrowski's theory of positive disintegration is a quite complex theoretical concept which can be characterized as a scientific model. Its analysis can provide us with an interesting look into extremely diverse topics, for example into a question of resocialisation of criminals committing sexual crimes. The aim of this article was the description of the presented theory and its potential usage in the practical issue of penalisation and resocialisation of criminals committing sexual crimes. Conclusions were drawn on both legal and political surfaces.
\end{abstract}

Keywords: psychology, sexual crimes, legal liability, theory of positive disintegration, personal growth. 